\title{
Spiro-cyclotriphosphazene with three functional end groups: synthesis and structural characterization of new polycyclotriphosphazenes with Schiff-base groups
}

\author{
Salah Mahdi Al-Shukri ${ }^{1), *)}$ (ORCID ID: 0000-0001-7110-4104), Ayad Tarik Mahmood ${ }^{2)}$ (0000-0003-0391-8194), \\ Othman A. Al Hanbali ${ }^{3)}(0000-0001-7110-4104)$
}

DOI: dx.doi.org/10.14314/polimery.2021.6.2

\begin{abstract}
A new tris-spiro-(3,4-dioxybenzaldehyde)cyclotriphosphazene [PNCHO] was synthesized from the condensation of hexachlorocyclotriphosphazene with 3,4-dihydroxybenzaldehyde in the presence of strong base. Further reaction of the trialdehydic cyclotriphosphazene based molecules [PNCHO] with three different dianilines (benzidine, 4,4'-methylenedianiline and 4,4'-Sulfonyldianiline) resulted in creation of a new poly(tris-spiro-3,4-dioxbenzene)cyclotriphosphazenes with Schiff-base groups [PNSB1-3]. The structures of [PNCHO] and the polycyclotriphosphazenes-schiff base derivatives were characterized by means of FTIR, ${ }^{1} \mathrm{H},{ }^{13} \mathrm{C}$ NMR and C.H.N elemental analysis. Differential scanning calorimetery (DSC) revealed a relatively high glass transition temperature $\left(135-175^{\circ} \mathrm{C}\right)$ of obtained polymers. Thermal gravimetric analysis (TGA) exhibited their good thermal stability (up to $375^{\circ} \mathrm{C}$ ). The char yield was about $36-42 \%$ at $700^{\circ} \mathrm{C}$. All polymers were self-extinguishable as the LOI (Limiting Oxygen Index) values were above $26 \%$ and this meets with the V-0 and V-1, classification (UL-94). No fumes, soot, or toxic gases emission were observed during burning. The polymers obtained can be used as environmentally friendly, flame-retardant materials.
\end{abstract}

Keywords: spirocyclotriphosphazene; polycyclophosphazene; poly(schiff-base); thermal stability; flame retardancy.

\section{Spiro-cyklotrifosfazen $\mathrm{z}$ trzema funkcyjnymi grupami końcowymi: synteza i charakterystyka struktury nowych policyklotrifosfazenów z grupami zasad Schiffa}

Streszczenie: Nowy tris-spiro-(3,4-dioksybenzaldehydo)cyklotrifosfazen [PNCHO] zsyntetyzowano w procesie kondensacji heksachlorocyklotrifosfazenu z 3,4-dihydroksybenzaldehydem w obecności silnej zasady. W wyniku reakcji trialdehydo cyklotrifosfazenów z trzema różnymi dianilinami (benzydyna, 4,4'-metylenodianilina i 4,4'-sulfonylodianilina) otrzymano poli(tris-spiro-3,4-dioksabenzeno)cyklotrifosfazeny z zasadami Schiffa [PNSB1-3]. PNCHO i pochodne policyklotrifosfazen-zasady Schiffa scharakteryzowano za pomocą analizy elementarnej (C, H, N), FTIR, ${ }^{1} \mathrm{H},{ }^{13} \mathrm{C}$ NMR. Metodą różnicowej kalorymetrii skaningowej (DSC) wykazano wysoką temperaturę zeszklenia $\left(135-175^{\circ} \mathrm{C}\right)$ otrzymanych polimerów. Metodą analizy termograwimetrycznej (TGA) potwierdzono ich dobrą stabilność termiczną (do $375^{\circ} \mathrm{C}$ ). Stopień zwęglenia po spaleniu wynosił w temp. $700^{\circ} \mathrm{C}$ ok. $36-42 \%$. Wszystkie polimery były samogasnące, ponieważ wartości LOI (Limiting Oxygen Index) przekraczały $26 \%$, co odpowiada klasie palności V-0 i V-1 (UL-94). Podczas spalania nie zaobserwowano emisji oparów, sadzy ani toksycznych gazów. Otrzymane polimery mogą znaleźć zastosowanie jako przyjazne dla środowiska materiały trudnopalne.

Słowa kluczowe: spirocyklotrifosfazen, policyklofosfazen, poli(zasada Schiffa), stabilność termiczna, ognioodporność.

\footnotetext{
1) Department of Chemistry, College of Science, Mustansiriyah University, Baghdad, 10052, IRAQ.

2) Polymer research unit, College of Science, Mustansiriyah University, Baghdad, 10052, IRAQ.

3) School of Pharmacy, the University of Sydney, Sydney NSW 2006, Australia.

*) Author for correspondence: salah_M@uomustansiriyah.edu.iq
} 
Hexachlorocyclotriphosphazene (HCP) is a very interesting inorganic cyclic compound which consists of three $\left[\mathrm{N}=\mathrm{PCl}_{2}\right]$ unites. The highly reactive $\mathrm{P}-\mathrm{Cl}$ bonds facilitate the substitution of the chlorine atoms with different organic and inorganic molecules that allow the designing of varied molecules with cyclotriphosphazene core. The type of substituents and the number of functional groups are the key variables in formulation of different organocyclotriphosphazene and polyorganocyclotriphosphazne.

Inclusion adducts, star-shaped, hyperbranched, and dendrimer are the most interesting and promising molecules in cyclophosphazene chemistry. These molecules are generally derived from oragnocyclotriphosphazenes which are commonly prepared via condensation reaction of HCP with varied substituents in different molar ratios afforded mono - to hexa - substituted organocyclotriphosphazenes [1-5].Spiro(o-phenyenedioxy)cyclotriphosphazenes are another interesting derivatives of organocyclotriphosphazene [6]. Many Spiro(o-phenyenedioxy) cyclotriphosphazenes with mono-, bis - or tris - substitution have been prepared, fully characterized and their thermal properties were investigated [7-11] N3P3Cl6, with N-alkyl-N'-mono(4-nitrobenzyl.

Most natural and/or synthetic hydrocarbon polymers, with no inherent flame retardant, once ignited will burn to completion under atmospheric condition. On the other hand, inorganic molecules, or polymeric materials with nitrogen and phosphorus atoms are generally nonflammable when they are subjected to tough burning conditions. Incorporation of these molecules either chemically bonded or physical blended to the industrial polymers, particularly in the construction, electronic and aviation industries are of great interest to avoid the generation of smokes, corrosive and super-toxic gases during fire accidents that causes great losses to society [12-14].

Recently, many research have prepared different types of cyclotriphosphazene core with hydroxyl - or amine terminated groups and subsequently initiate polymerization with different monomers for preparation of high thermally stable and halogen free flame retardants such as polyester [15]Inc.A six-arm star-shaped poly( $\varepsilon$ caprolactone, polyurethane [16], polyamide [17], polyimide [18], and epoxy resin [19].

Polycyclotriphosphazene containing different types of aromatic diamines is one of the most important class of high performance polymers, because it possesses unique thermal and oxidative stability, excellent chemical resistance, and superior fire retardation.

Bonding of cyclotriphosphazenes to the carbon-nitrogen double bond via aryl group is new approach for the synthesis of cycolotriphosphazene bearing Schiff-base (imine) unites. These compounds have been gaining attention because of their exceptional properties. Therefore, the structural characteristics, thermal properties, fire retardation, absorbance, liquid crystalline, biomedicine, chelation of different metals and semiconduc- tor properties of these compounds have been extensively studied by many research [20-29].

An initial literature survey indicated that, the only work that has been done for linear poly-phosphazene with Schiff base linkage groups, was earlier reported by Allcock in 1981 [30], and to the best of our knowledge no more works has been reported after that. Therefore, to gain insight into the structural features and to fill this apparent gap in the literature, new poly(tris-spiro-3,4-dioxbenzene)cyclotriphosphazenes bearing three Schiffbase groups have been synthesized from the reaction of tris-spiro-(3,4-dioxybenzaldehyde)cyclotriphosphazene with different dianilines (benzidine, 4,4'-methylenedianiline and 4,4'-Sulfonyldianiline), the structural characteristics, thermal properties and flame retardation of the new halogen free polymers are investigated in this paper.

\section{EXPRIMENTAL PART}

\section{Materials}

Hexachlorocyclotriphosphazene $\left(\mathrm{NPCl}_{2}\right)_{3}$ (Sigma-Aldrich, Japan) was purified by recrystallization from n-hexane. Triethylamine Reagent-grade (Merck) was pre-dried over potassium hydroxide, distilled and stored under Ar gas. 1,4-dioxane (Merck) was freshly distilled before use from sodium metal in an atmosphere of nitrogen. Benzidine, 4,4'-methylenedianiline and 4,4'-Sulfonyldianiline (Merck) and other chemicals were used as Laboratory-grade supplied without further purification.

\section{Methods}

Fourier-transform infrared (FT-IR) spectra were recorded on a SHIMADZU 8400s FTIR spectrophotometer in the range of $4000-400 \mathrm{~cm}^{-1} .{ }^{1} \mathrm{H}-$ and ${ }^{13} \mathrm{C}-\mathrm{NMR}$ spectra were obtained using an Oxford Varian 300 NMR spectrometer operated at $300 \mathrm{MHz}$ for proton and $75 \mathrm{MHz}$ for carbon. Chemical shifts were recorded in parts per million relative to tetra-methylsilane (TMS) (0.00 ppm).

Thermal gravimetric analyses (TGA) were performed on a TA Instruments-Discovery (TGA) in the range of ambient temperature to $700{ }^{\circ} \mathrm{C}$ at a heating rate of $10{ }^{\circ} \mathrm{C} / \mathrm{min}$ under stream of $\mathrm{N}_{2}$ flow.

Differential scanning calorimetry (DSC) analysis was recorded on a NETZSCH DSC 204 F1 Phoenix (Germany) at a heating rate of $10^{\circ} \mathrm{C} / \mathrm{min}$ in a temperature range of $0-250^{\circ} \mathrm{C}$. The glass transition temperatures $\left(\mathrm{T}_{\mathrm{g}}\right)$ were determined from the inflection point of the DSC thermogram.

C, H, N elemental analysis was obtained using EuroEA3000 elemental analyzer. A limiting oxygen index (LOI) values were determined using an instrument from Fangyuan Instrument (DG) Co., Ltd.

The ability of prepared polymeric materials to extinguish the flame after ignition and its dripping behavior was estimated by UL-94 vertical test. The test was made using the NK8017A (NKISKY Instrument Co., Ltd, China). The 
dimensions of the sample were as follows: length $127 \mathrm{~mm}$, width $12.5 \mathrm{~mm}$, and a thickness of about $3.0 \mathrm{~mm}$.

\section{Synthesis of products}

\section{Synthesis of tris(3,4-dioxybenzaldehyde) cyclotriphosphazene PNCHO.}

This reaction was carried out under anhydrous conditions in an inert nitrogen atmosphere. In a $100 \mathrm{~mL}$ round bottom flask a solution of (11.91g, $43.14 \mathrm{mmol})$ 3,4-dihydroxybenzaldehyde and $(24.0 \mathrm{~mL}, 172.58 \mathrm{mmol})$ of triethylamine in $20 \mathrm{~mL}$ 1,4-dioxane was added dropwise via an addition funnel over a period of 10 minutes to a solution of $(10 \mathrm{~g}, 28.76 \mathrm{mmol})$ of hexachlorocyclotriphosphazene in $20 \mathrm{~mL}$ of 1,4-dioxane. A white salt began to precipitate within seconds, and the reaction was refluxed for $2 \mathrm{hr}$. and continued stirring at room temperature for another 24 hrs. The progress of the reaction was monitored by thin layer chromatography TLC technique on silica gel plates using n-hexane-THF (1-8). Upon completion, the precipitated triethylamine hydrochloride salt was filtered off and the solvent removed under reduced pressure. The sticky material was reconstituted in $30 \mathrm{ml}$ of methylene chloride and washed with water in separate funnel. The organic layer was received over anhydrous $\left(\mathrm{Na}_{2} \mathrm{SO}_{4}\right)$ and then filleted. The solvent was removed under reduced pressure and the sticky material was recrystallized from hot benzene, resulting in a slightly brown color solid material with a yield of $54 \%$.

PNCHO; M.p > $250{ }^{\circ} \mathrm{C}$; FTIR $\left(\mathrm{cm}^{-1}\right) \mathrm{KBr}$ window, 3072 (Ar-H), 2719 (H-CO), $1681(\mathrm{C}=\mathrm{O}), 1593,1495,1450$ (C=C, Ar), 1296 (C-O), 1268, $1186(\mathrm{P}=\mathrm{N}), 1114$ (P-O-C), 970 weak absorption (P-N skeletal vibration). ${ }^{1} \mathrm{H}$ NMR (DMSO$\left.\mathrm{d}_{6}\right), \delta \mathrm{ppm}=\mathrm{Ha}(9.73, s ; \mathrm{CHO}), \mathrm{Hb}(7.27,7.25, d ; \mathrm{Ar}-\mathrm{H}), \mathrm{Hc}$ (6.83 and 6.81, $d$; Ar-H), Hd (ס 7.35, s; Ar-H). ${ }^{13} \mathrm{C}$ NMR (75.4 MHz), $\delta$ ppm=, C1 190.65, C2 130.69, C3 116.84, C4 115.84, C5 145.66, C6 151.07, C7 123.86. Elemental analysis $\mathrm{C}, \mathrm{H}, \mathrm{N}$, Calculated for $\mathrm{C}_{21} \mathrm{H}_{18} \mathrm{~N}_{3} \mathrm{O}_{9} \mathrm{P}_{3}: \mathrm{C}, 46.40 ; \mathrm{H}, 3.31 ; \mathrm{N}$, 7.74 \%. Found: C, 45.04; H 3.30; N, $7.78 \%$.

\section{Synthesis of polycyclotriphosphazenes containing Schiff-base linkage groups PNSB1-3.}

The polycyclotriphosphazenes with Schiff-base linkage groups were synthesized by the reaction of compound
PNCHO with three dianilines (benzidine, 4,4'-methylenedianiline, 4,4'-Sulfonyldianiline) afforded three different polymers abbreviated as PNPSB1-3, respectively.

To a solution of PNCHO $(5 \mathrm{~g}, 9.20 \mathrm{mmol})$ dissolved in $10 \mathrm{~mL}$ of Absolut ethanol in a two necked round bottom flask fitted with a condenser and a guard tube, a mixture of dianilines and drops of glacial acetic acid in $20 \mathrm{~mL}$ of ethanol were added via dropping funnel. The mixture was first heated and then refluxed with continuous stirring. The reactions were monitored using thin layer chromatography TLC technique on silica plated using n-hexane-THF (1-8). The brown solid product was filtered and then washed twice with hot ethanol to remove any unreacted dianiline. The product was then dried at $70^{\circ} \mathrm{C}$ under reduced pressure for 6 hours. A dark red solid material (yield $\approx 32-42 \%$ ) was obtained. A summary of the synthetic procedure of the compounds is given in Table 1 .

PNSB1, FTIR ( $\mathrm{cm}^{-1}$ ) on KBr window, 3015 (Ar-H); 2855 $\mathrm{N}=(\mathrm{C}-\mathrm{H})$ imine; 1655 (CH=N); 1592, 1576, 1514 (C=C, Ar); 1298 broad band (C-N and C-O); 1216, $1185(\mathrm{P}=\mathrm{N}) ; 1074$ (P-O-C); 974 (weak absorption, P-N skeletal vibration). ${ }^{1} \mathrm{H}$

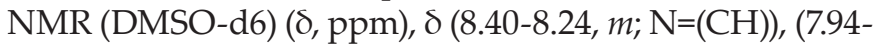
6.48, $m$; Ar-H). ${ }^{13} \mathrm{C}$ NMR ( $\delta$, ppm), C2 126.41, C3 115.94, C4 114.66, C5 146.10, C6 146.36, C7 123.33, C8 159.89, C9 152.16, C10 121.35, C11 126.41, C12 130.20.

PNSB2, FTIR ( $\left.\mathrm{cm}^{-1}\right) \mathrm{KBr}$ window, 3031 (Ar-H); 2947, 2905, (C-H aliph); $2835 \mathrm{~N}=(\mathrm{C}-\mathrm{H})$ imine; 1610 (CH=N); 1510, 1442 (C=C, Ar); 1296 broad band (C-N and C-O); 1268, 1186 $(\mathrm{P}=\mathrm{N}) ; 1114$ (P-O-C); 971 (weak absorption, P-N skeletal vibration). ${ }^{1} \mathrm{H}$ NMR ppm (DMSO-d6), $\delta$ ppm $=(8.54-8.42$, m; $\mathrm{N}=(\mathrm{CH}),(8.54-6.61, m ; \mathrm{Ar}-\mathrm{H}),(3.87-3.84, m ; \mathrm{C}-\mathrm{H}$ methylene). ${ }^{13} \mathrm{C}$ NMR. $\delta$ ppm = C2 126.52, C3 118.77, C4 116.00, C5 146.14, C6 146.38, C7 122.96, C8 160.04, C9 152.65, C10 121.90, C11 127.56, C12 124.31, C13 46.06.

PNSB3; FTIR $\left(\mathrm{cm}^{-1}\right) \mathrm{KBr}$ window, 3059 (Ar-H); 2840 $\mathrm{N}=(\mathrm{C}-\mathrm{H})$ imine; 1637(CH=N); 1596, 1578 (C=C, Ar); 1203 (C-N); 1267 (C-O); 1223, $1183(\mathrm{P}=\mathrm{N}) ; 1146,1105$, 1074( $\mathrm{O}=\mathrm{S}=\mathrm{O}$ ); $1071 \mathrm{P}-\mathrm{O}-\mathrm{C} ; 964$ (weak absorption, P-N skeletal vibration). ${ }^{1} \mathrm{H}$ NMR ppm (DMSO-d6), $\delta$ ppm= , (8.52; $\mathrm{N}=(\mathrm{CH})),(7.77-6.5, m, \mathrm{Ar}-\mathrm{H}) .{ }^{13} \mathrm{C} \mathrm{NMR}, \delta \mathrm{ppm}=\mathrm{C} 2128.54$, C3 115.90, C4 113.04, C5 147.25, C6 146.46, C7 124.97, C8 158.56, C9 153.10, C10 121.09, C11 126.91, C12 130.11.

T a b l e 1. Synthesis of the polymers

\begin{tabular}{c|c|c|c|c|c|c|c}
\hline $\begin{array}{c}\text { PNCHO } \\
\mathrm{g} / \mathrm{mmol}\end{array}$ & Dianiline & $\mathrm{g} / \mathrm{mmol}$ & $\begin{array}{c}\text { Reaction time } \\
\mathrm{hr}\end{array}$ & $\begin{array}{c}\text { Yield } \\
\%\end{array}$ & Color & Solubility & Schiff base \\
\hline $5 / 9.20$ & Benzidine & $2.54 / 13.80$ & $72 \mathrm{hr}$ (reflux) & 32 & dark red & $\begin{array}{c}\text { DMSO, DMF, } \\
\text { Acetone } \\
\text { DMSO, DMF, } \\
\text { Acetone } \\
\text { PNSB1 } \\
\text { PNSB2 } \\
\text { DMSO, DMF, } \\
\text { Acetone }\end{array}$ & $\begin{array}{c}\text { dark red } \\
\text { PNSB3 }\end{array}$ \\
\hline
\end{tabular}




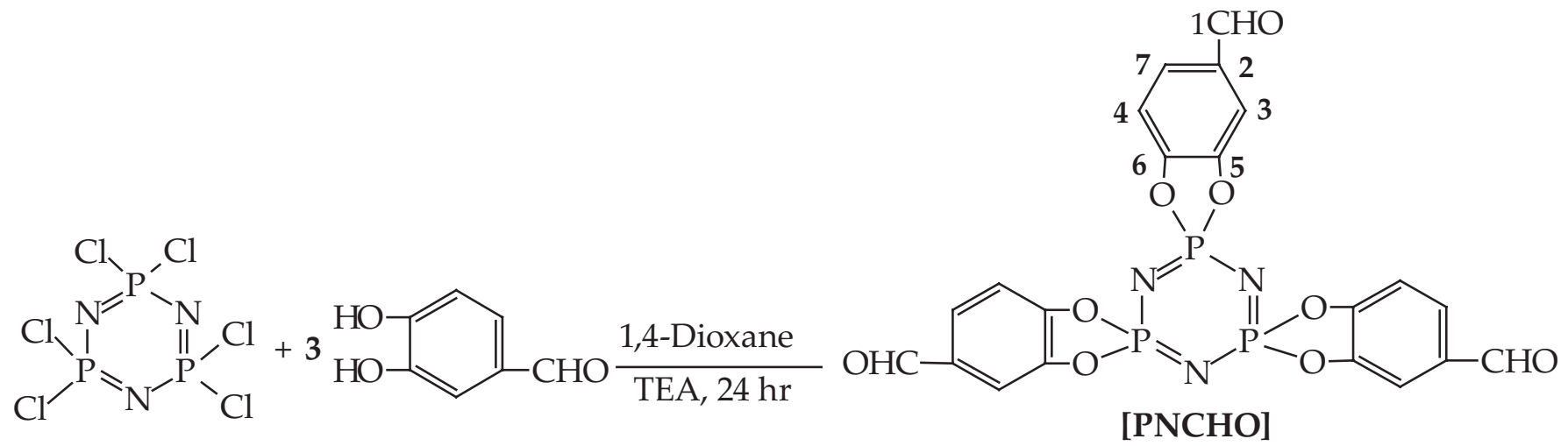

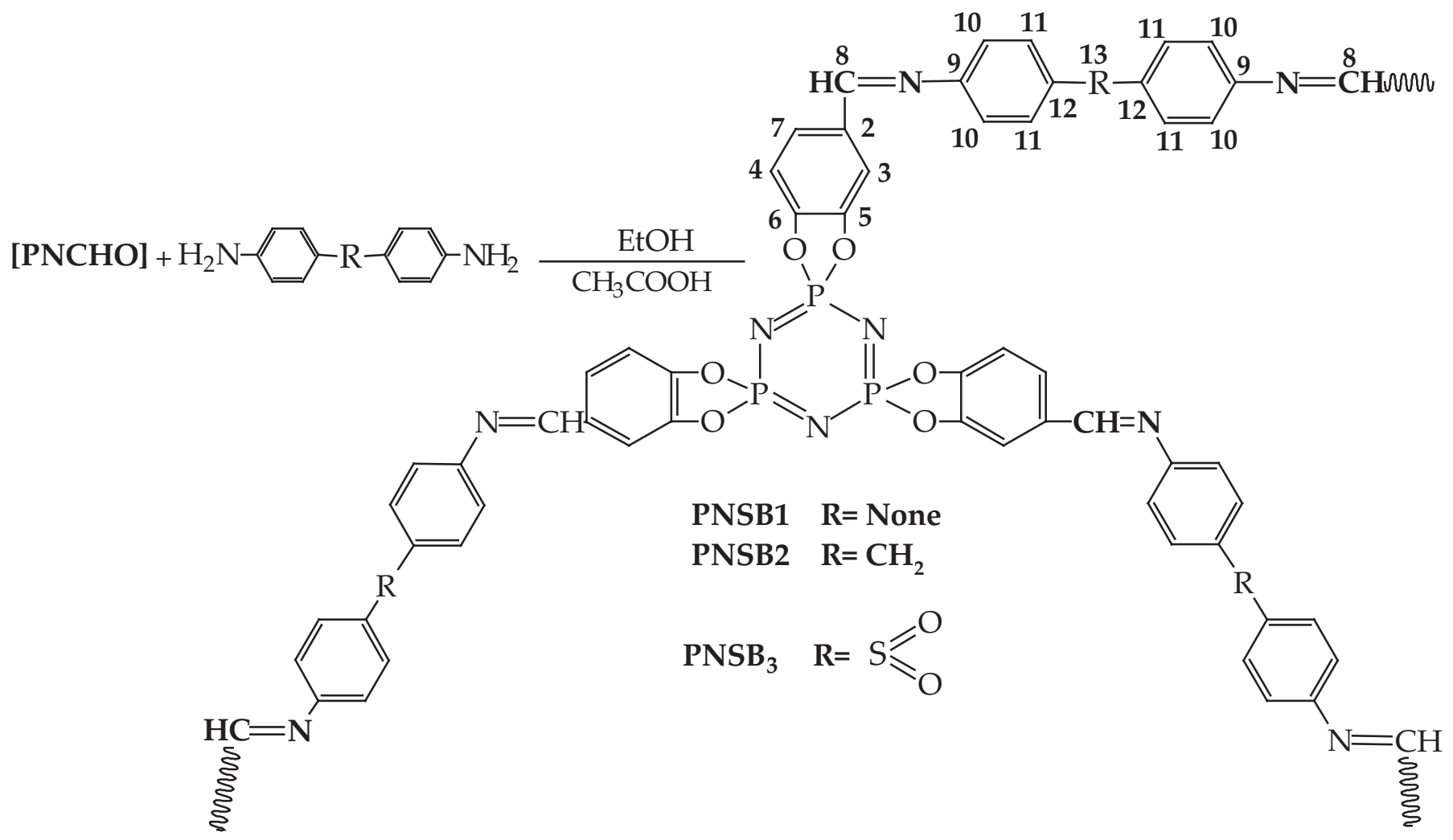

Scheme 1. Synthesis of PNCHO and PNSB1-3

\section{RESULTS AND DISCUSSION}

\section{FTIR and ${ }^{1} \mathrm{H}$ NMR Analysis}

The overall reaction scheme of the research work is presented in Scheme 1. The first step involves the condensation reaction of HCP with three moles of 3,4-dihydroxybenaldehyde in the presence of triethylamine as a $\mathrm{HCl}$ removal to form the fully substituted tris(3,4-dioxybenzaldehyde)cyclotriphosphazene PNCHO. The FTIR spectrum of this compound given in Fig. 1 shows absorption bands at $3072 \mathrm{~cm}^{-1}$ attributed to $\mathrm{C}-\mathrm{H}$ aromatic and band at $2717 \mathrm{~cm}^{-1}$ assigned for the aldehydic $\mathrm{C}-\mathrm{H}$ stretching while band at 1681 is for $\mathrm{C}=\mathrm{O}$ of aldehyde groups. Peaks at 1593 , $1495,1450 \mathrm{~cm}^{-1}$ are attributed to $\mathrm{C}=\mathrm{C}$ of aromatic rings and strong peak at $1296 \mathrm{~cm}^{-1}$ is for the $\mathrm{C}-\mathrm{O}$ bond. Bands at $1268,1186 \mathrm{~cm}^{-1}$ are assigned to asymmetric and symmetric stretching of $\mathrm{P}=\mathrm{N}$ and at $970 \mathrm{~cm}^{-1}$ is due to P-N skele- tal vibration. Absence of a band at $3200 \mathrm{~cm}^{-1}$ of the $\mathrm{O}-\mathrm{H}$ stretching bonds and the disappearance of peaks at 600 and $526 \mathrm{~cm}^{-1}$ of $\mathrm{P}-\mathrm{Cl}$ bond are indicating a complete replacement of chlorine atoms by 3,4-dihydroxybenaldehyde.

The ${ }^{1} \mathrm{H}$ NMR spectrum of PNCHO in Fig. 2, shows absence of the hydroxyl signal which confirms the successful substitution of the chlorine atoms by 3,4-dihydroxybenzaldehyde. The signal that appeared at $9.73 \mathrm{ppm}$ represents the aldehyde proton and singlet peak at $7.35 \mathrm{ppm}$, doublet at 7.27, 7.25 and another doublet at 6.83, $6.81 \mathrm{ppm}$ represent the aromatic protons in the phenyl rings.

The ${ }^{13} \mathrm{C}$ NMR (Fig. 3) spectrum is in good agreement with the ${ }^{1} \mathrm{H}$ NMR result which clearly shows appearance of peaks due to aldehyde carbon (C1) at $190.65 \mathrm{ppm}$ and (C5, C6) at 151.07 and $145.66 \mathrm{ppm}$ due to ArC-(OP). Other peaks due to aromatic carbons (as labeled in Figure 1) are clearly appeared. 


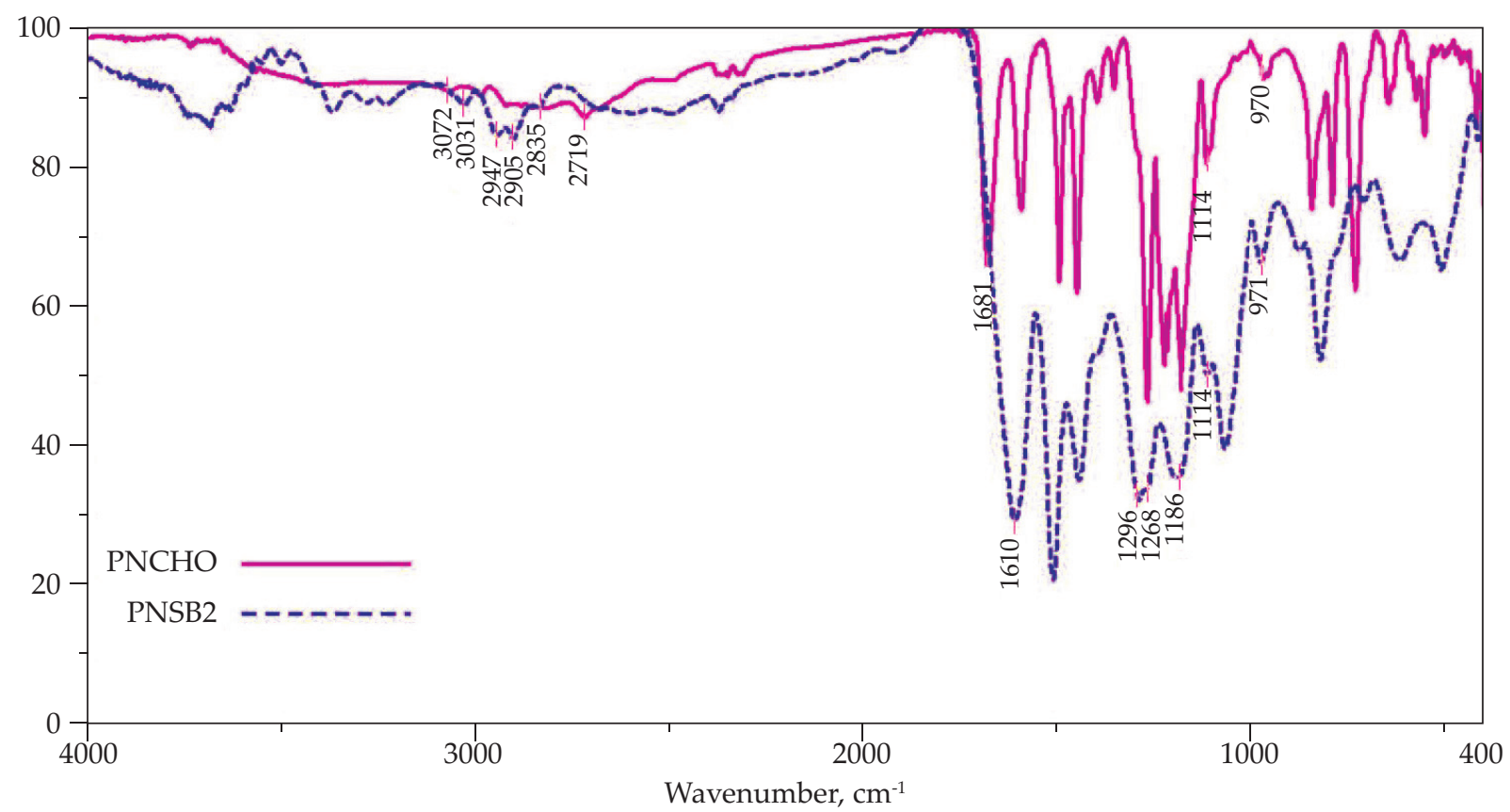

Fig. 1. FTIR spectra of PNCHO and PNSB2

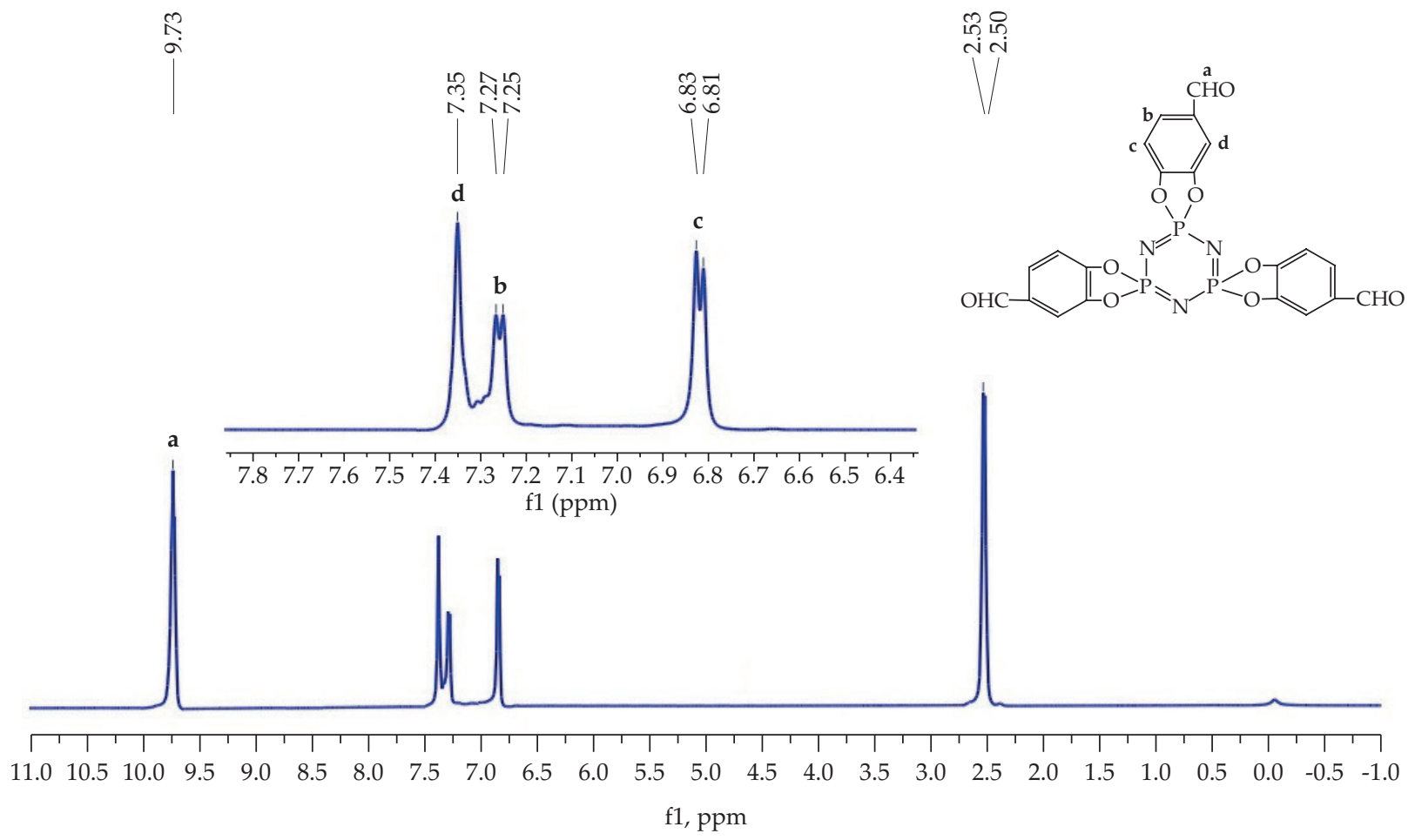

Fig. 2. ${ }^{1} \mathrm{H}$ NMR spectrum of PNCHO

The second step of the reaction is the direct polymerization of PNCHO with different dianilines (benzidine, 4,4'-methylenedianiline, 4,4'-Sulfonyldianiline). The FTIR spectra of PNSB1, PNSB2 and PNSB3 shows almost the same broad absorption patterns with slight differences. For example the spectrum of PNSB2 given in Fig. 4, reveals clear disappearance of the aldehyde $\mathrm{C}=\mathrm{O}$ stretching at $1681 \mathrm{~cm}^{-1}$ and appearance of new important absorption band due to $\mathrm{HC}=\mathrm{N}$ bond at $1610 \mathrm{~cm}^{-1}$. The spectrum shows absence of the aldehydic C-H stretching $2719 \mathrm{~cm}^{-1}$ and appearance of the characteristic absorptions due to $\mathrm{N}=(\mathrm{C}-\mathrm{H})$ imine bond at $2835 \mathrm{~cm}^{-1}$. Peaks due to $\mathrm{C}-\mathrm{N}, \mathrm{P}=\mathrm{N}$ and P-O-C appear as broad bands at 1268, 1186, $970 \mathrm{~cm}^{-1}$, respectively.

The ${ }^{1} \mathrm{H}$ NMR spectra of polycyclotiphosphazene schiff base (PNSB1-3) in general shows broad and multiple resonances which is largely due to restricted molecular rotation and repeating units being situated in marginally different electronic environments. It is noteworthy that after $24 \mathrm{hrs}$ of refluxing in ethanol the reaction was incom- 


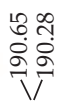

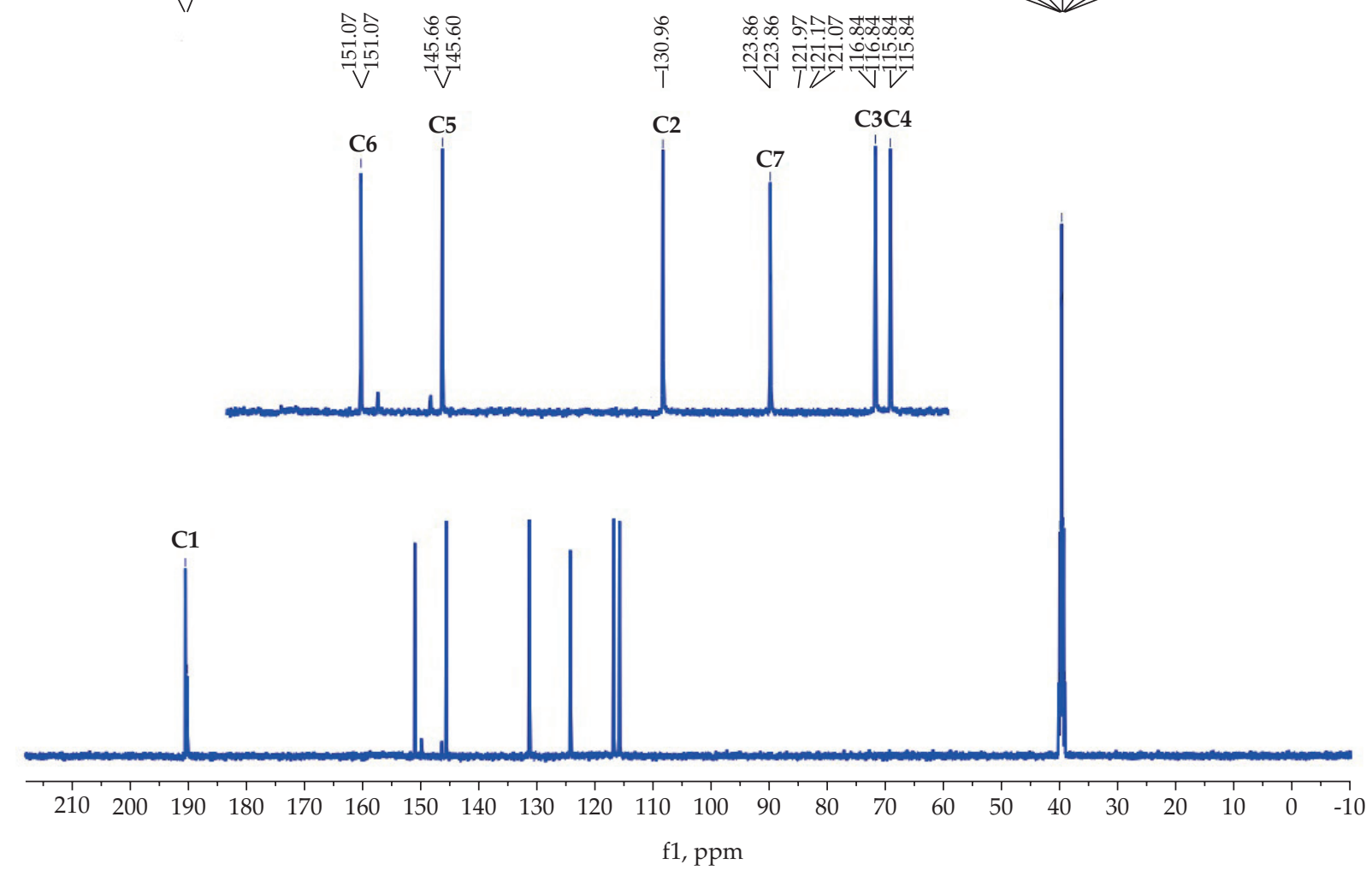

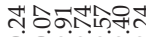

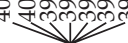

Fig. $3 .{ }^{13} \mathrm{C}$ NMR spectrum of PNCHO

a)

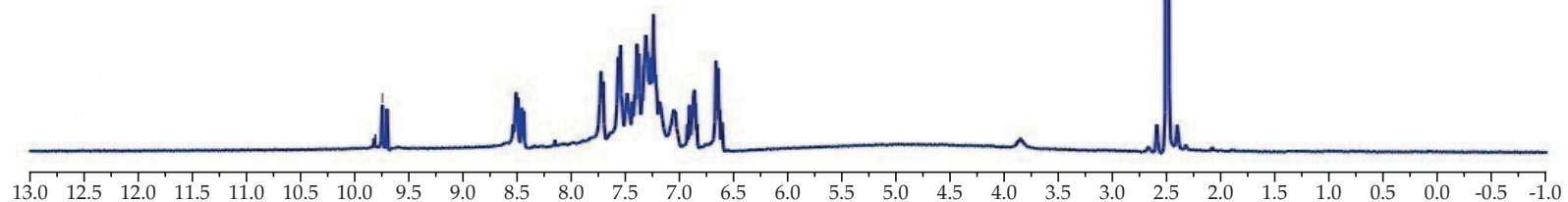

b)
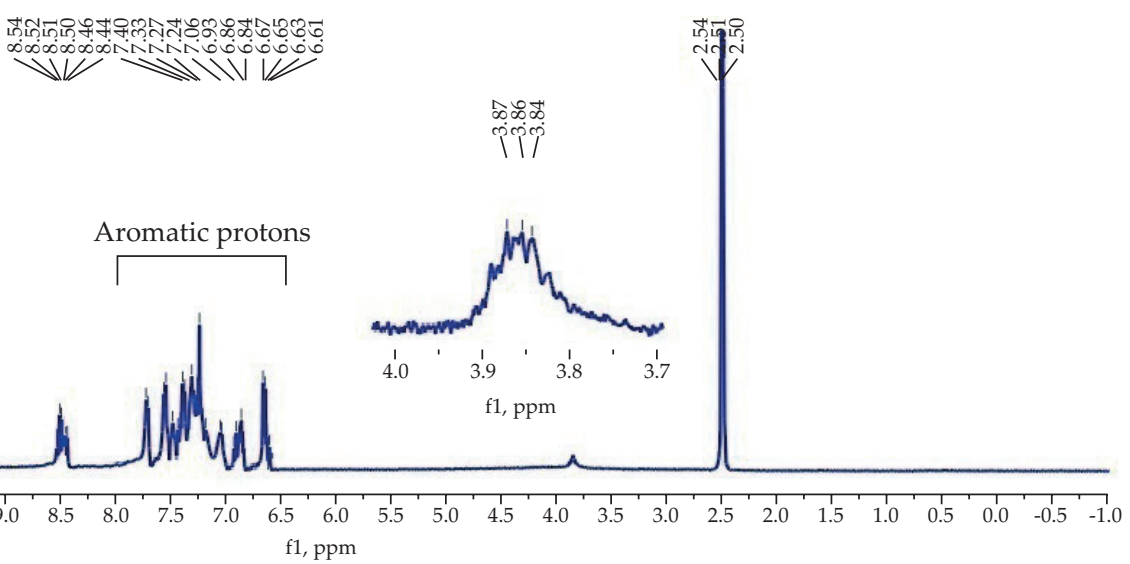

Fig. 4. ${ }^{1} \mathrm{H}$ NMR spectrum of PNSB2: a) after $24 \mathrm{hrs}$ of refluxing in ethanol b) after $72 \mathrm{hrs}$ of refluxing in ethanol 


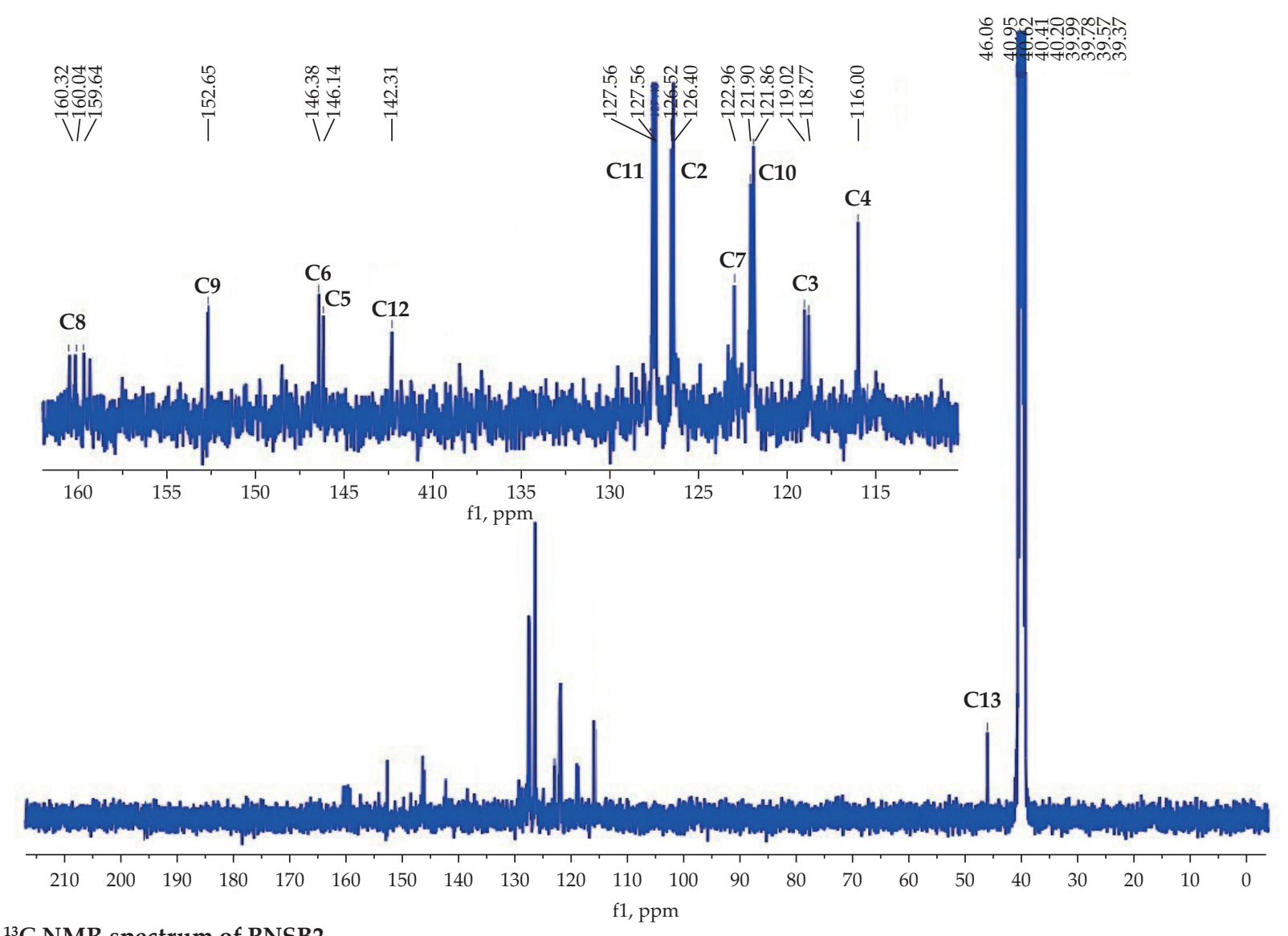

Fig. 5. ${ }^{13} \mathrm{C}$ NMR spectrum of PNSB2

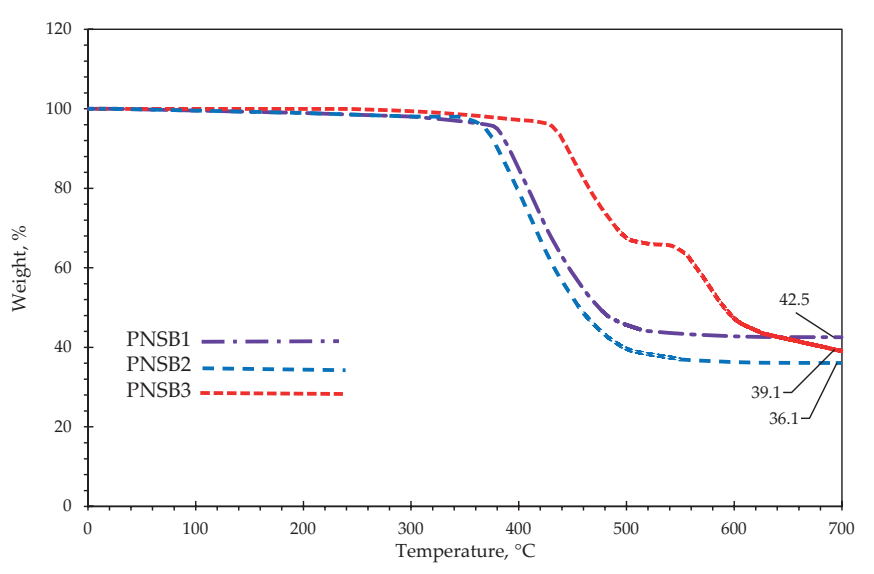

Fig. 6. TGA curves of PNSB1-3

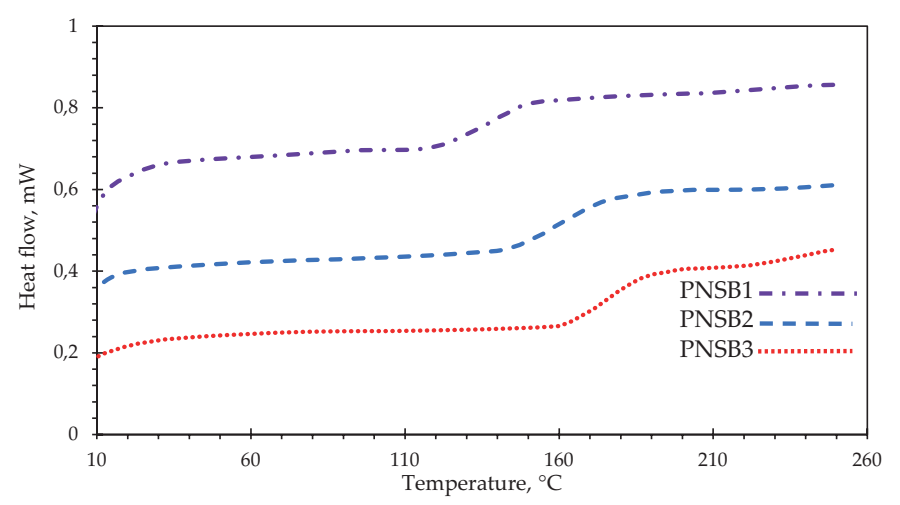

Fig. 7. DSC thermograms of PNSB1-3 plete as indicated by the appearance of both aldehydic and imine protons Fig. 4a. Therefore, in order to reach a completion of the reaction with a best percentage yield, the reaction time was extended to not less than $72 \mathrm{hrs}$ of refluxing with continuous stirring (Fig. 4b). The important features in FTIR spectrum are the disappearance of the aldehyde proton at $9.85 \mathrm{ppm}$ and appearance of new peak at $8.68 \mathrm{ppm}$ that ascertains the presence of imine proton $\mathrm{H}-\mathrm{C}=\mathrm{N}$. Other peaks due to aromatic protons appear at 8.71-7.51 and 7.40-6.61 ppm and signal at 3.86 is due to methane group.

${ }^{13} \mathrm{C}$ NMR spectrum in Fig. 5 shows clear multiple peaks of C8 at 160.04 ppm and C13 at 46.06 ppm and disappearance of $\mathrm{C} 1$ peak at $190.14 \mathrm{ppm}$. Hence, these data indicated that the reaction of $\mathrm{PNCHO}$ with different dianilines was successfully afforded by a new polycyclotriphosphazene with Schiff base linkage groups.

\section{Thermal analysis test}

A stack plot of TGA curves of PNSB1-3 with flow of $50 \mathrm{~mL} / \mathrm{min}$ nitrogen shows a good thermal stability, indicated by the absence of any significant weight loss up to $350^{\circ} \mathrm{C}$ (Fig. 6). The curves reveal a strong destabilization zones between $370-500^{\circ} \mathrm{C}$ and also no major difference between them. They clearly show typical single-stage decomposition in the temperature range of $366-500^{\circ} \mathrm{C}$ which is due to the weight loss of the dianiline groups. However, the curve of PNSB3 shows better thermal sta- 
$\mathrm{T}$ a b l e 2. Thermal properties and flammability behavior of polymers

\begin{tabular}{|c|c|c|c|c|c|c|c|}
\hline \multirow{2}{*}{ Product } & \multirow{2}{*}{$\mathrm{Tg},{ }^{\circ} \mathrm{C}$} & \multirow{2}{*}{$\begin{array}{l}\text { First decom. } \\
\left.\text { Step, }{ }^{\circ} \mathrm{C}^{\mathrm{a}}\right) \\
(\text { wt. } \%)\end{array}$} & \multirow{2}{*}{$\begin{array}{c}\text { Second } \\
\text { decom. Step, } \\
{ }^{\circ} \mathrm{C}^{\text {a) }}(\text { wt. \%) }\end{array}$} & \multirow{2}{*}{$\begin{array}{c}\text { Char wt. } \% \text { at } \\
700^{\circ} \mathrm{C}\end{array}$} & \multicolumn{2}{|c|}{ LOI } & \multirow{2}{*}{ UL-94 } \\
\hline & & & & & b)Found & c) Calc. & \\
\hline PNSB1 & 135 & $441(55)$ & - & 42 & 33 & 34.3 & $\mathrm{~V}-0$ \\
\hline PNSB2 & 163 & $433(63)$ & - & 36 & 31 & 31.9 & V-1 \\
\hline PNSB3 & 175 & 469 (32) & 579 (26) & 39 & 34 & 33.1 & $\mathrm{~V}-0$ \\
\hline
\end{tabular}

a) Maximum weight loss temperature

b) Data obtained experimentally

c) values were theoretically calculated from van Krevelen of empirical equation:

$\mathrm{LOI}=17.5+0.4(\mathrm{cy})$, where $\mathrm{cy}=$ char yield obtained from TGA analysis at $700^{\circ} \mathrm{C}[32]$ it is found that the amount of char and the amount of incombustible gases that may be formed in thermal decomposition are very important quantitative measures of flame resistance. For a large number of model substances the char residue upon pyrolysis has been determined. The residue is found to be very clearly related to the chemical structure of the polymer, so much so that the amount of char can be predicted from the structure. Finally, it has been demonstrated that there is a very significant relation between the pyrolysis residue (\%)

bility as the decomposition started at $428^{\circ} \mathrm{C}$. This may be due to the presence of chemically stable $\mathrm{S}=(\mathrm{O})_{2}$ groups at the polymer backbone. The curve of PNSB3 displays two distinctive weight loss stages in the range of 428-511 and $449-610^{\circ} \mathrm{C}$. The latter stage may be due to the loss of bulky $\mathrm{S}=(\mathrm{O})_{2}$.

The amount of accumulated char yields discernible from TGA curves at $700^{\circ} \mathrm{C}$ were fair and ranging from 42 to $36 \%$ (Table 2). Presence of this amount of char is probably due to the partial scission and repolymerizing of cyclotriphosphazene rings with a subsequent increase in crosslinking density, resulting in formation of thick char layer which reduced the transmission of heat to the underlying polymeric materials [31].

The DSC thermograms of PNSB1-3 given in (Fig. 7) reveals clear endothermic transition which is caused by the glass transition temperature $(\mathrm{Tg})$ appeared at 135, 163 and 175, respectively. This somewhat high $\mathrm{Tg}$ is due to the formation of low degree of cross linked polymer that formed between the trifunctional cyclotriphosphazene rings through Schiff-base linkage groups. This might restrict the movement of polymer chain segments and thus raised the $\mathrm{Tg}$ values.

\section{Flammability characteristics}

The flammability characteristics of the products were evaluated by limiting oxygen index (LOI) measurements; the results are summarized in (Table 2). The limiting oxygen index value denotes the minimum fraction of oxygen in an oxygen-nitrogen mixture that is necessary to support a stable combustion of the specimen in a candle-like manner for three minutes. Since one fraction of air contains approximately 21 vol.\% of oxygen, therefore materials with LOI values less than $21 \%$ are classified as flammable and they will probably continue burning to completion in atmospheric air once they are ignited, while materials with a LOI above $21 \%$ are classified as flame retardant because their combustion cannot be sustain for three minutes in normal atmospheric conditions without the support of an external source. On the other hand materials with LOI more than $26 \%$ are classified as self - extinguishing and above $60 \%$ are non-flammable [33].

From the LOI values given in (Table 2), it can be seen that the LOI values of PNSB1-3 are relatively high . This is in agreement with the generally accepted notion that the presence of phosphazene moieties may provide acid sources during pyrolysis that promote dehydration of the matrix, leading to the formation of a protective char layer which can act as an isolative barrier limiting the amount of heat released and prevent further pyrolysis to the underlying polymeric materials and also reducing the progress of thermo-oxidation by limiting the access of oxygen to the polymeric materials and consequently inhibit combustion in a solid phase.

The UL 94-V test results are also shown in Table 2. The burning time of the specimens after the first and second ignition $\left(t_{1}\right)$ and $\left(t_{2}\right)$ are recorded. During burning of the specimens no dripping was observed for all polymers. The (t1) plus ( $t 2$ ) was found to be $\leq 10 \mathrm{~s}$ for PNSB1, and PNSB3 therefore they are classified as V-0 grade, while PNSB2 is classified as V-1 grade because the burning times was $\leq 30$. It is obvious that the prepared polycyclotriphosphazenes with schiff base linkage groups possess excellent flame retardant efficiency, undoubtedly due to nitrogen-phosphorus synergistic effect in both condensed and vapor phase.

\section{CONCLUSION}

New polycyclotriphosphazenes with Schiff-base linkage groups were prepared from the reaction of newly synthesized trialdehydic cyclotriphosphazene based molecules $\mathrm{PNCHO}$ with three different diphenylene diamines (benzidine, 4,4'-methylenedianiline, 4,4'-diaminodiphenyl sulfone). The structures of prepared compounds were characterized by different spectroscopic techniques and elemental analysis which afford sufficient information of the successful reaction to form the final products Polycyclotriphosphazenes with Schiffbase linkage groups. 
The thermal analysis of these polymers suggests that the synthesized polymers possess good thermal stability and high $\mathrm{T}_{\mathrm{g}}$ values. Because of phosphorous and nitrogen flame-retardant synergy, the prepared polymers exhibited good fire resistance characteristics as they are self-extinguished having LOI above $30 \%$ and they past the UL94 V-0 and V-1 classification. These synthesized high-performance, non-flammable polymers can be potentially applied in heat resistance industries, such as: automobile, electronics, construction, and others.

\section{ACKNOWLEDGMENTS}

Authors would like to thank the Department of Chemistry and the Polymer Research Unit, Mustansiriyah University, Baghdad, Iraq https://uomustansiriyah.edu.iq/ for providing facilities to accomplish this research work.

\section{REFERENCES}

[1] Huang X.Z., Jing Q., Lin Y.H. et al.: Chemistryselect 2020, 5 (30), 9486. https://doi.org/10.1002/slct.202001910

[2] You G., Cai Z., Peng H. et al.: Phosphorus, Sulfur, and Silicon the Related Elements 2014, 189 (4), 541. https://doi.org/10.1080/10426507.2013.829838

[3] HeQ., Dai H., Tan X. et al.: Journal of Materials Chemistry C 2013, 1 (43), 7148. DOI:10.1039/C3TC31371A

[4] Liu W., Zhang S., Qiao Z., Li Q., Li X., Wang H.: Colloids and Surfaces A: Physicochemical and Engineering Aspects 2018, 541, 17. https://doi.org/10.1016/j.colsurfa.2018.01.025

[5] Şenkuytu E., Eçik E.T.: Spectrochimica Acta Part A: Molecular and Biomolecular Spectroscopy 2017, 173, 863. https://doi.org/10.1016/j.saa.2016.10.052

[6] Allcock, H.R.: Journal of the American Chemical Society 1964, 86 (13), 2591.

[7] Okumuş A. et al.: Research on Chemical Intermediates 2016, 42 (5), 4221. https://doi.org/10.1007/s11164-015-2271-3

[8] Işiklan M., Sonkaya Ö., Çoşut B. et al.: Polyhedron 2010, 29 (6), 1612.

[9] Tunca U., Erdogmus A.L.I., Hizal G.: Journal of Polymer Science Part A: Polymer Chemistry 2001, 39, 2993. https://doi.org/10.1002/pola.1279

[10] Dez I., Jaeger R.: Phosphorus Sulphur. and Silicon 1997, $130,1$.

[11] Kumar N.S., Swamy C.K.: Polyhedron 2004, 23, 979.

[12] Xu M.J., Xu G.R., Leng Y. et al.: Polymer Degradation and Stability 2016, 123, 105. https://doi.org/10.1016/j.polymdegradstab.2015.11.018

[13] Li J. et al.: Journal of Applied Polymer Science 2015, 132 (44), 42733. https://doi.org/10.1002/app.42733

[14] Yang R., Hu W., Xu L. et al.: Polymer Degradation and Stability 2015, 122, 102.

https://doi.org/10.1016/j.polymdegradstab.2015.10.007
[15] Ye W. et al.: Journal of Applied Polymer Science 2017, 134 (2), 1. https://doi.org/10.1002/app.45295

[16] Song X., Chi H., Li Z. et al.: Polymers 2020, 12 (4), 740. https://doi.org/10.3390/polym12040740

[17] Wang C., Hu F., Yang K. et al.: RSC Advances 2015, 5 (107), 88382. https://doi.org/10.1039/C5RA15598C

[18] Devaraju S., Selvi M., Alagar M.: International Journal of Polymer Analysis and Characterization 2018, 23 (1), 29. https://doi.org/10.1080/1023666X.2017.1387021

[19] Zarybnicka L. et al.: Polymers 2021, 23 (1), 1. https://doi.org/10.3390/polym13010008

[20] Jamain Z., Khairuddean M., Guan-Seng T.: RSC Advances 2020, 10 (48), 28918.

DOI: 10.1039/D0RA03812A

[21] Aslan F., Öztürk A.İ., Binici M.: Inorganica Chimica Acta 2020, 502, 119308. https://doi.org/10.1016/j.ica.2019.119308

[22] Doğan S., Tümay S.O., Balci C.M. et al.: Turkish Journal of Chemistry 2020, 44 (1), 31. DOI: 10.3906/kim-1905-60

[23] Xu J., Ling T.C., He C.: Journal of Polymer Science Part A: Polymer Chemistry 2008, 46 (4), 4691. https://doi.org/10.1002/pola.22800

[24] Tümer Y., Yuksektepe Ç., Bati H. et al.: Phosphorus, Sulfur, and Silicon and the Related Elements 2010, 185 (12), 2449. https://doi.org/10.1080/10426501003692078

[25] Jamain Z., Khairuddean M., Saidin S. A.: Journal of Molecular Structure 2019, 1186, 293. https://doi.org/10.1016/j.molstruc.2019.02.01

[26] Jamain Z., Khairuddean M., Guan-Seng T.: Molecules 2020, 25, 2122. https://doi.org/10.3390/molecules25092122

[27] Pektaş S. et al.: Inorganica Chimica Acta 2018, 474, 51. https://doi.org/10.1016/j.ica.2018.01.016

[28] Tarassoli A., Sedaghat T., Ansari-Asl Z.: Journal of Industrial and Engineering Chemistry 2014, 20 (4), 2287. https://doi.org/10.1016/j.jiec.2013.10.003

[29] Aslan F., Demirpence Z., Tatsiz R. et al.: Zeitschrift fur Anorganische und Allgemeine Chemie 2008, 634 (6-7), 1140. https://doi.org/10.1002/zaac.200700586

[30] Allcock H.R., Austin P.E.: Macromolecules1981, 14 (6), 1616. https://doi.org/10.1021/ma50007a002

[31] Jin W., Yuan L., Liang G. et al.: ACS Applied Materials and Interfaces 2014, 6 (17), 14931. https://doi.org/10.1021/am502364k

[32] Krevelen D.V.: Polymer 1975, 16 (8), 615.

[33] Anioł B., Jankowski D.: Technical Transactions 2018, 9, 57. DOI: $10.4467 / 2353737 X C T .18 .131 .8970$

Received 10 V 2021. 